\title{
The Influence of Project Dimensions in Risks Management: A Literature Review
}

\author{
Eng. Philemon Z. Msomba, \\ ${ }^{1}$ Doctoral Student, \\ Department of Structural and Construction Engineering, \\ College of Engineering and Technology (COET), \\ University of Dar es salaam, Tanzania
}

\author{
Dr. Matiko Samson, \\ ${ }^{2}$ Lecturer, \\ Department of Structural and Construction Engineering, \\ College of Engineering and Technology (COET), \\ University of Dar es Salaam, Tanzania
}

\author{
Dr. Ramadhani, S Mlinga \\ ${ }^{3}$ Lecturer, \\ Department of Structural and Construction Engineering, \\ College of Engineering and Technology (COET), \\ University of Dar es Salaam, Tanzania
}

\begin{abstract}
Construction projects are known to be overly affected by risks. Comprehensive identification of major sources and causes of risk in construction project plays a critical role towards managing project risks. There are many publications on factors that influence the extent of risks in construction projects. This paper reviews literature to identify project dimensions which significantly influence risk management in construction projects. The paper identified six project dimensions considered to significantly influence risk management within construction projects. Project characteristics (complexity, type, size, site, uncertainty), Project team (clients, contractors, consultants), project funding (financier, disbursement, mode of payments), project implementation boundaries (scope, budget, duration, quality), Stakeholders (user, customer, regulators), procurement implementation arrangement (procurement, delivery method and contract strategy) are most influential project dimensions influencing risk management processes. The construction professionals should take cognizance of these project dimensions in managing risk at the early stage of the project so as to minimize the effect of risk on project performance.
\end{abstract}

Keywords: Projects Performance, Project Dimensions, Risk Management, Project Life Cycle

\subsection{INTRODUCTION}

Construction projects are often big, complex, one of the kinds and involve a lot of uncertainties. These are major ingredients for risk. It is not surprising therefore, that successful construction project performance is associated with effective risk management (Zwikael and Ahn, 2011). Risk is an important issue to contractors as well as clients and consultants of the construction industry. The risks affecting a project are highly dependent on the nature and dimensions of the project. As Baccarini (1996) puts it, "certain project dimensions provide a basis for determining the appropriate managerial actions required to complete a project successfully. Some projects are technology intensive, some are labour intensive and some demand huge sums of money and some are very sensitive to political and economical settings. This diversity of features and project dimensions has led to development of a number of project risk management approaches and frameworks. Various studies have found a positive relationship between project risk management and project success. In essence, there is consensus that understanding the causes of risks in construction project is the key to successful risk management and consequently successful project performance (McFarlan, 1981; Raz et al., 2002; Sommer et al, 2009). This paper reviews the literatures in construction risk management to identify project dimensions that are considered to crucially influence the risk profile of a construction project.

\subsection{PROJECT DIMENSIONS}

A project dimension can be defined as one of the aspects, attributes, elements, or factors that make up the project. Unfortunately, there is no consensus as to what are the dimensions of the construction project. There are however, commonly identified dimensions established from previous works including, scope, schedule, finance, management, teams, stakeholders, technology, complexity, uncertainty, procurement, contract, project site, regulatory mechanism, type, and size of the project (Baccarini, 1996; Dissanayaka and Kumaraswamy, 1999; Ling, 2004; Georgy and Chang, 2005; Chang and Ibbs, (2006); Vidal and Marle, 2008; Maylor et al., 2008; Ruben and Ger, 2008; and Cho et al., 2009, Hwang et al (2009); Babalola and Ojo, 2010; Bloch et al., 2012). Based on the literature review the researcher has presented project dimensions in six groups as indicated in Table 1 to Table 3 below and further explained in the proceeding sections. 
Table 1 Project dimensions influencing risk management from various Authors

\begin{tabular}{|c|c|c|c|c|c|c|}
\hline \multirow{3}{*}{ Authors } & \multicolumn{6}{|c|}{ Proposed project dimensions } \\
\hline & \multicolumn{5}{|c|}{ Project characteristics } & \multirow{2}{*}{ 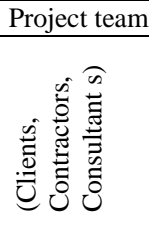 } \\
\hline & 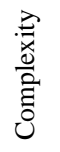 & 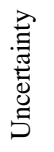 & $\sum_{i}^{0}$ & $\stackrel{\widetilde{N}}{\stackrel{N}{n}}$ & 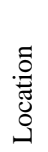 & \\
\hline \multicolumn{7}{|l|}{$\begin{array}{ll}\text { Babalola } & \text { and } \\
\text { Ojo(2010) }\end{array}$} \\
\hline $\begin{array}{l}\text { Hwang et al } \\
(2009)\end{array}$ & & & $\checkmark$ & $\checkmark$ & $\checkmark$ & \\
\hline $\begin{array}{l}\text { Chang and Ibbs } \\
\text { (2006) }\end{array}$ & & $\checkmark$ & $\checkmark$ & $\checkmark$ & & \\
\hline $\begin{array}{lll}\begin{array}{l}\text { Song } \\
(2003)\end{array} & \text { et al. }\end{array}$ & & & $\checkmark$ & & & \\
\hline $\begin{array}{l}\text { Bloch et al. } \\
(2012)\end{array}$ & $\checkmark$ & & & & & $\checkmark$ \\
\hline $\begin{array}{l}\text { Ruben and Ger } \\
\text { (2008) }\end{array}$ & $\checkmark$ & $\checkmark$ & $\checkmark$ & $\checkmark$ & $\checkmark$ & $\checkmark$ \\
\hline $\begin{array}{l}\text { Chan et al } \\
(2004)\end{array}$ & $\checkmark$ & $\checkmark$ & & & $\checkmark$ & $\checkmark$ \\
\hline $\begin{array}{l}\text { Chan et al. } \\
\text { (2001) }\end{array}$ & & & & & & $\checkmark$ \\
\hline $\begin{array}{l}\text { Enshassi, et al. } \\
\text { (2009) }\end{array}$ & & & & & & $\checkmark$ \\
\hline $\begin{array}{l}\text { Dimensions } \\
\text { adopted in this } \\
\text { study }\end{array}$ & & & $\checkmark$ & & & $\checkmark$ \\
\hline
\end{tabular}

Table 2 Project dimensions influencing risk management from various Authors

\begin{tabular}{|c|c|c|c|c|}
\hline \multirow{3}{*}{ Authors } & \multicolumn{4}{|c|}{ Proposed project dimensions } \\
\hline & \multicolumn{3}{|c|}{ Project funding } & \multirow{2}{*}{ 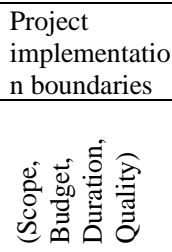 } \\
\hline & 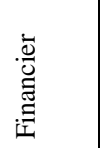 & 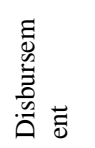 & 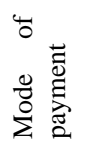 & \\
\hline Babalola and Ojo (2010) & $\checkmark$ & $\checkmark$ & $\checkmark$ & \\
\hline \multicolumn{5}{|l|}{ Hwang et al (2009) } \\
\hline Chang and Ibbs (2006) & & & & $\checkmark$ \\
\hline Song et al. (2003) & & & & $\checkmark$ \\
\hline \multicolumn{5}{|l|}{ Bloch et al. 2012} \\
\hline Ruben and Ger (2008) & $\checkmark$ & & $\checkmark$ & $\checkmark$ \\
\hline Chan et al (2004) & $\checkmark$ & $\checkmark$ & $\checkmark$ & $\checkmark$ \\
\hline Chan et al. (2001) & $\checkmark$ & & $\checkmark$ & \\
\hline Enshassi, et al. (2009) & & & & $\checkmark$ \\
\hline $\begin{array}{l}\text { Dimensions adopted in } \\
\text { this study }\end{array}$ & & $\checkmark$ & & $\checkmark$ \\
\hline
\end{tabular}

Table 3 Project dimensions influencing risk management from various Authors

\begin{tabular}{|c|c|c|c|c|}
\hline \multirow{3}{*}{ Authors } & \multicolumn{4}{|c|}{ Proposed project dimensions } \\
\hline & \multirow{2}{*}{ 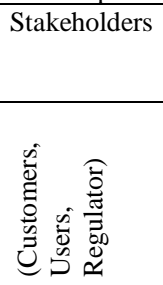 } & \multicolumn{3}{|c|}{$\begin{array}{l}\text { Procurement } \\
\text { implementation } \\
\text { arrangement }\end{array}$} \\
\hline & & 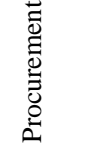 & 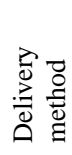 & 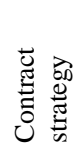 \\
\hline \multicolumn{5}{|l|}{ Babalola and $\mathrm{Ojo}(2010)$} \\
\hline Hwang et al (2009) & & & $\checkmark$ & $\checkmark$ \\
\hline \multicolumn{5}{|l|}{ Chang and Ibbs (2006) } \\
\hline Song et al. (2003) & & & & $\checkmark$ \\
\hline Bloch et al. (2012) & $\checkmark$ & & & \\
\hline Ruben and Ger (2008) & $\checkmark$ & $\checkmark$ & $\checkmark$ & $\checkmark$ \\
\hline Chan et al (2004) & $\checkmark$ & $\checkmark$ & $\checkmark$ & \\
\hline Chan et al. (2001) & & $\checkmark$ & & \\
\hline Enshassi, et al. (2009) & $\checkmark$ & & & \\
\hline $\begin{array}{l}\text { Dimensions adopted in } \\
\text { this study }\end{array}$ & $\checkmark$ & & $\checkmark$ & \\
\hline
\end{tabular}

\subsection{Project characteristics}

Project characteristics have been identified as major causes of risks to construction projects, the extent of its impact is a major concern to the effective risks management. This group of project dimension includes project complexity, project type, project size, project site, and project uncertainty. These should be considered as will influence time, cost and risk.

\subsubsection{Complexity}

The complexity of the project is defined by the parts that constitute the project, the number of parts, the characteristic of each part and how they are interconnected. Projects and their nature have had many changes over time, that one of these changes is the complexity of project components and their relationships. In addition to the size and scope of the project, the large numbers of experts, project team members, project stakeholders, variety of software and specialized tools for each section and obvious or hidden relationship among them have increased the complexity (Baccarini, 1996; Azim et al., 2010). The complexity of project management is in turn dependent on the complexity of the project. Thus projects have become risky undertakings, and complexity plays an important role in this, since according to Vidal and Marle (2008) project complexity is the property of a project which makes it difficult to understand, foresee and keep under control its overall behaviour. Maylor (2003) uses the term resource complexity. When the number of units, such as project members or activities, increase the project complexity increases. The level of risk is always related to the project complexity (Darnall and Preston, 2010). As complex projects require prodigious management skills and tools, it is important for practitioners to be able to assess the level of complexity they have to deal with and the risks associated with it, in order to adjust the resources and capabilities to the specific project needs (Shenhar, 2001). 
The construction industry operates in a very uncertain environment where conditions can change due to the complexity of each project (Sanvido et al., 1992). Therefore, a more projects specific approach to manage projects risk is required

\subsubsection{Project type (e.g housing estate, roads, dam, office building, and refurbishment)}

The risks affecting a project are highly dependent on the nature and characteristics of the project. Studies by Shenhar and Dvir (1996) and Shenhar (2001) demonstrated an interlink between project type and risk management methods that connect to project success. Some projects are technology intensive, some are labour intensive, and also some demand huge sums of money and some are very sensitive to political and economical settings. There are different kinds of projects that can be defined in a number of ways and for each project type there are different types of risks. Although different projects may have more or fewer risks than others, no project is completely free of risk. There are many challenges that make projects unique, including management of numerous, synchronized and complex activities within tight schedules and fixed budgets.

\subsubsection{Project size (e.g value, number of stories, floor area and $\mathrm{km}$ of road)}

There are a number of risks which can be identified in the construction industry and which can be faced in each construction project regardless of its size and scope. Project size refers to the size of the infrastructure to be delivered at the end of the project. It is determined by the number of elements (components, parts, functions, tasks and specialists) included in the infrastructure. Uncertainties increase with the size of the project (physical size, financial value, manpower requirements, to mention but a few). The bigger the project is, the larger the number of potential risks that may be faced. Several factors can stimulate risk occurrence. The problem multiplies with the size of the project as uncertainties in project outcome increase with size (Dey, 2011). Cleden (2009) claims that complexity is a factor that can limit a project; the bigger and more complex a project is, the more resources are required to complete it. Besner and Hobbs (2012) report that large projects, projects with long planning horizons, projects requiring substantial resources, projects of significant novelty, and complex projects, are significantly more likely to need a comprehensive, detailed risk management process.

\subsubsection{Project site}

Construction projects are invariably unique one-off designs and are built on sites that are also unique in nature (Turner, 1990). The decision-making about the location of a construction site is an important risk management practice at planning stage. The location has a strong influence of project design and structural characteristics and thus the execution of the project. The location of the project will influence its risk management processes. For example heavily sloped sites require extensive stepping or cut and fill operations and such sites may be dangerous and adversely affect the working conditions and productivity of operatives and plant output, these kinds of sites require more effective risk managements plan and methodologies. Dealing with unforeseen ground conditions is highly risk in construction projects from the fact that can affect cost of the project as well as time of project execution.

\subsubsection{Uncertainty}

The most common interpretation of uncertainty in the extant literature on projects is the risk and/or uncertainty caused by unreliable information or lack thereof (Chapman, 2006; Kutsch and Hall, 2005); novel, immature or unproven technology (Meijer et al, 2007), project complexity (Williams, 2005; Floricel and Miller, 2001) and other unpredictable factors. A very common mistake in the management of construction projects is to overlook the uncertain characteristic of the project environment and believe that projects are deterministic (Sanderson, 2012). Uncertainty is dwelling in the instability of circumstances and assumptions upon which a project is based. Theoretically it can be defined as a lack of certainty involving variability and/or ambiguity. Uncertainty surfaces in the decision makers mind because of information deficit (Macheridis and Nilsson, 2004). This reflects the level and extent of the gap between the knowledge required to perform the project tasks and the knowledge available to the project team at the beginning of the project (Lebcir and Choudrie, 2011). . Project uncertainty renders the project complex to manage because the suitable means, methods, and capabilities to be deployed in a project are not always well known at the start of project work. Uncertainty is seen as a factor that affects complexity positively, high uncertainty increases project complexity (Williams, 2005). It is also important to emphasise that uncertainty changes over time and that actors in projects can influence uncertainty through their behaviour (Jensen et al, 2006). Uncertainty management is concerned as managing perceived threats and opportunities and their risk implications but also managing the various sources of uncertainty which give rise to and shape risk, threat and opportunity (Chapman and Ward, 2003).

\subsection{Project team}

All construction projects are unique and carry their own risks. Such projects involve a number of key parties concerned, starting with the owner, contractor, consultant and suppliers. All parties involved in a project inevitably carry certain risks (Pheng and Chuan, 2006). A lot of participants - individuals and organisations are actively involved in the construction project, and they interests may be positively or negatively affected as a result of the project execution or project completion (PMI, 2008). Different participants with different experience and skills usually have different expectations and interests (Dey and Ogunlana, 2004). Project team members can increase the uncertainty of a project's outcome, such as team member turn-over, staffing build up, insufficient knowledge among team members, cooperation, motivation, and team communication issues. Working team must analyse the business activities of all alliance members and identify various risk factors in business activities and their characters (Li and Liao, 2007; Li et al. 2007). In order to complete project successfully, it is critical that every project team member has a good understanding of the fundamental project requirements, which include project planning, organizing, 
motivating, directing and controlling (Cleland and Ireland, 2002) and has positive attitude. Risk management helps the key project participants - client, contractor, consultant, and supplier - to meet their commitments and minimize negative impacts on construction project performance in relation to cost, time and quality objectives.

\subsection{Project funding}

Projects funds need to be effectively planned to ensure success. Chen (2007) mentions that for a project to be successful there should be adequate fund allocated to finance its completion. Jackson (2010) added that project funds availability is an important factor that influences successful delivery of a project. It is an established fact that the mode of funding of a project determines to a large extent its success rate. The need to have satisfactory project performance makes efficient management of funding for projects imperative. When projects are faced with the difficulties of irregularity and delay of release of funds for payment of works, the performance is threatened. A study on construction projects in Tanzania (Kikwasi, 2012) revealed that, inadequate budgets for construction projects played a significant part in delayed completion of the construction projects. Milestones payments are not made on time due to organizational lapses or bureaucracy. Slow or delayed payment to contractors for completed works is a very common complaint of contractors about project's client. Failure to provide payment on time to contractors for the completed work will make it difficult for the contractors to meet project objectives. Inadequate cash flow leads to delay in delivery of materials and equipment to the site and delay in payment of workers' salaries.

Another aspect of project funding is disbursement of funds. Funds are not adequately released during relevant phases of projects' execution causing financial risks. Disbursement is a critical aspect of project financial management since projects are modeled on capital budgeting principles and as such, all relevant cash flows associated with the undertaking must be ascertained with a fair degree of accuracy so that the desirable returns are achieved within the set time periods. Therefore all decisions made during project implementation invariably have financial implications hence the need for utmost care and diligence in arriving on the same (Loader, 2002; Strenman, 2012).

\subsection{Project implementation boundaries}

Project Management Book of Knowledge, 2004 refers to project success being measured in terms of time, cost, scope, quality and customer satisfaction (PMI, 2004). Getting a project right is a balancing act. Time, cost and quality tend to pull in different directions, and all have different risks, but a successful project needs to strike the right balance between all three (Wallace and Blumkin, 2007). It is expected of project participants to effectively manage the cost, time and risk impacts of all project activities, and complete the project within the project constraints regardless of any challenges. The key success indicators of construction project risk management processes include completing the project with cost and time, within the planned budget and duration, and within the required quality, safety, and environmental limits. These boundaries are interrelated where each of them is affecting and affected by the others. To manage project risks more effectively, a fresh approach in project management is required. An accurate cost estimating and scheduling should be sought in order to meet the overall project objective (Faridi and El-Sayegh, 2006).

\section{5 Stakeholders}

Project stakeholders are individuals or groups who will be impacted by, or can influence the success or failure of the project's work and its deliverables (Lynda, 2009). There are many sources of risk and uncertainty in construction projects, which include the performance of construction parties, resources availability, environmental conditions, involvement of other parties, contractual relations (Faridi and El-Sayegh, 2006). Projects in construction, as well as in any other industries, are subject to a variety of external and internal influences. These influences result, among others, from the interests of individuals or groups which claim to have a stake on the project and its outcome (Olander and Landin, 2005). Stakeholders' interests and influences are not constant and can vary from one stage to another and even from time to time in a particular stage of the project lifecycle (Olander, 2007; Aaltonen et al., 2008; Ward and Chapman, 2008;). A project is successful when it achieves its objectives and meets or exceeds the expectations of the stakeholders. The checklist of stakeholders in a construction project is often large and would include the owners and users of facilities, project managers, facilities managers, designers, shareholders, legal authorities, employees, subcontractors, suppliers, process and service providers, competitors, banks, insurance companies, media, community representatives, neighbors, general public, government establishments, visitors, customers, regional development agencies, the natural environment, the press, pressure groups, civic institutions, etc. (Newcombe, 2003). The process of risk assessment and communications is shaped with the institutions regulating the conduct of the construction industry.

Varied stakeholder interests (Turner and Muller, 2004), and poor communication (Doloi, 2009) are not the only factors which could negatively affect the project's risk management and/or outcome. The number of stakeholders involved or interested in the project can dramatically increase the complexity and uncertainty of the situation. Construction stakeholders can be categorized as primary and secondary stakeholders. Primary stakeholders include client, consultant, and Project Managers who are considered as directly connected to the project. While Secondary stakeholders include investors, suppliers, employees, sub-contractors, third party, banks, governmental authorities, pressure groups, trade associations, and communities. Each stakeholder usually has different interests and priorities that can place them in conflict or disagreements with the project (Karlsen, 2008).

\subsection{Procurement implementation arrangement}

Not all forms of procurement method are appropriate for particular project types, as client objectives and priorities invariably differ (Skitmore and Marsden, 1998). The objectives and priorities of a client need to be matched to a procurement system. To do this effectively, it is essential that the characteristics of various procurement systems and 
selection methods available are understood by clients and their advisors before a procurement method is selected. The procurement method chosen will influence the degree of integration and collaboration that will take place between project team members, particularly the contractor. The greater the integration between project members the more likely a project is in achieving a successful outcome (Dissanayaka, 1998). The establishments of an appropriate procurement strategy that identifies and prioritises key project objectives as well as reflects aspects of risk, and establishes how the process will be managed are keys to a successful project outcome (AlBahar and Crandall, 1990). A procurement strategy should be developed that balances risk against the project objectives that are established at an early stage during project planning.

One of the most important decisions made by any owner embarking on a construction project is the choice of the project delivery method including how the project will be designed and constructed (CMAA, 2012). AIA (2007) defines a project delivery method as "the comprehensive process of assigning the contractual responsibilities for designing and constructing a project". A project delivery method identifies the primary parties taking contractual responsibility for the performance of the work (Gransberg, 2013). Understanding these roles, relationships, and responsibilities, as defined by the project delivery method, is essential for assigning risk ownership. In order to select the most appropriate project delivery method for the project, owners must develop a number of criteria based on the particular project and then compare the characteristics of the delivery method, and how they would positively affect those criteria. One of the most essential of these criteria is the "ability to manage risk effectively and exert control over the project" (Ghavamifar and Touran, 2009). A construction project's success can be measured by how its delivery method controls scope, costs, schedule, and quality (Love et al, 1998). Because the project delivery method will become the framework for management of the project, special consideration must be taken to fit the project delivery method to the needs of the project, as well as the risk factors that must be addressed. Responsibilities for meeting project objectives relating to cost, quality, and time vary with each delivery method, and thus each delivery method offers a different level of risk to the project team member (AIA, 2007). While many risk management processes and tools may be successfully applied for the management of risk in any project delivery method, some project delivery methods may be better suited to the application of risk management processes in specific projects.

\subsection{CONCLUSION}

Based on the review the study concludes that different project dimensions cause significant influence on risk management practices. Thus, effective risk management will require comprehensive understanding of how each of the discussed dimensions affects the achievement of project goals. This paper recommends comprehensive evaluation of the influence of each of the above dimensions on the probability and consequence of risky events in construction project performance, and takes appropriate actions earlier on.

\section{REFERENCES}

[1] Aaltonen, K., Jaakko, K. and Tuomas, O. "Stakeholder salience in global project," International Journal of Project Management, Vol. 26, pp. 509-516, 2008.

[2] Al-Bahar, J. and Crandall, K.C. "Systematic risk management approach for construction projects," Journal of Construction Engineering Management, Vol. 116, pp. 533-546, 1990.

[3] American Institute of Architects (AIA), Integrated Project Delivery: A Guide, American Institute of Architects, Washington, D.C, 2007.

[4] Azim S, Gale A, Lawlor-Wright T, Kirkham R, Khan A, "The importance of soft skills in complex projects," International Journal of Managing Projects in Business Vol. 3, pp. 387-401, 2010

[5] Babalola M.O and Ojo, G. K. Risk and Uncertainties in construction Clients' Cash Flow Forecast, West Africa Built Environment, Res. (WABER) Conference, School of Construction Management and Engineering, Reading University, UK, pp. 469-476, 2010.

[6] Baccarini, D. "The concept of project complexity- a review," International Journal of Project Management, Vol.14, No. 4, pp.201204, 1996.

[7] Besner, C. and Hobbs, B. "An empirical identification of project management toolsets and a comparison among project types," Project Management Journal, Vol.43, pp.5, pp. 24-46, 2012

[8] Bloch, M., Blumberg and Laartz, J. Delivering large- scale IT projects on time, on budget, and on value. McKinesey Quarterly pp. October1-6, 2012 .

[9] Chapman, C and Ward, S, "Transforming project risk management into project uncertainty management," International Journal of Project Management, Vol. 21, No. 2, pp. 97-105, 2003.

[10] Chapman, C. "Key Points of Contention in Framing Assumptions for Risk and Uncertainty Management," International Journal of Project management, Vol. 24, pp. 303-313, 2006.

[11] Chang, A. S, and Ibbs, W. "System model for analyzing design productivity, Journal of Management and Engineering Vol. 22, No.1, pp27-34, 2006.

[12] Chen, S. P. "Analysis of critical paths in a project network with fuzzy activity times," European Journal of Operational Research, Vol.183, No.1, pp.442-459, 2007.

[13] Cho K, Hong T, Hyun, C. "Effect of project characteristics on project performance in construction projects based on structural equation model," International Journal Expert Systems with Appl, Vol. 36, No.7, 2009. September, Tarrytown, NY, USA

[14] Cleland, D.I. and Ireland, L.R. Project Management: Strategic Design and Implementation, McGraw-Hill, Boston, MA, 2002

[15] Cleden, D. Managing project uncertainty, Abingdon: Ashgate Publishing Group, 2009.

[16] CMAA. An Owner's Guide to Project Delivery Methods: Advancing Professional Construction and Program Management Worldwide, Construction Management Association of America, McLean, Virginia, 2012.

[17] Darnall, R. and Preston, J.M. Project Management from Simple to Complex, Flat World Knowledge, Inc, 2010

[18] Dey P. K, Ogunlana S. O. "Selection and application of risk management tools and techniques for build-operate-transfer projects,' Industry Management Data System Vol.104, No. 4 pp. 334-346, 2004.

[19] Dey P. K.. Issues and challenges of managing projects in India: A case study. In: Budhwar PS, Varma A, editors. Doing business in India: Building research-based practice New York: Routledge, 2011.

[20] Dissanayaka, S.M. Comparing Procurement and Non-Procurement Contributors to Project Performance, Unpublished Master of Philosophy, The University of Hong Kong, Hong Kong SAR, 1998.

[21] Dissanayaka S. M, Kumaraswamy M. M Comparing contributors to time and cost performance in building projects, Building and Environment, Vol. 34, pp.31-42, 1999.

[22] Doloi, H. "Relational partnerships: the importance of communication, trust and confidence and joint risk management in achieving project success," Construction Management and Economics, Vol. 27, pp. 1099 1109, 2009.

[23] Faridi, A. and El-Sayegh, S. "Significant factors causing delay in the UAE construction industry," Journal of Construction Management and Economics. Vol. 24, No.11, pp.1167-1176, 2006. 
[24] Floricel, S. and Miller, R. "Strategizing for Anticipated Risks and Turbulence in Large-Scale Engineering Projects. International Journal of Project Management, Vol.19, pp.445-455, 2001.

[25] Georgy, M. E, Chang, L. Quantifying Impacts of Construction Project Characteristics on Engineering Performance: A Fuzzy Neural Network Approach, Computing in Civil Engineering, Proceedings of the (2005), ASCE International Conference on Computing in Civil Engineering, July 12-15, 2005 Cancun, Mexico

[26] Ghavamifar, K., and Touran, A. "Alternative Project Delivery Systems: Applications and Legal Limits in Transportation Projects." Journal of Professional Issues in Engineering Education and Practice, Vol. 134, No. 1, pp.106-111, 2008.

[27] Hwang, B.G., Thomas, S.T, Haas, C.T, and Caldas, C.H. Measuring the Impact of Rework on construction Cost Performance, Journal of construction Engineering and Management Vol.135, No.3, pp.187-198, 2009.

[28] Jackson K.. Fundamentals of Project Performance Measurement, 2010. available from [http://alarcos.inf-cr.uclm.es/doc/pgsi/doc/otros/pmbok-( Accessed on November, 2017)

[29] Jensen, C., Johannson, S., and Löfström, M. "Project relationships - A model for analysing interactional uncertainty," International Journal of Project Management, Vol. 24, No.1, pp.4-12, 2006.

[30] Karlsen, J.T. "Forming relationships with stakeholders in engineering projects," European Journal of Industrial Engineering, Vol. 2, No. 1, pp. 35-49, 2008

[31] Kikwasi, G.J. "Causes and Effects of Delays and Disruptions in Construction Projects in Tanzania," Australasian Journal of Construction Economics and Building, Conference Series, Vol.1, No.2, pp.52-59, 2012

[32] Kutsch, E., and Hall, M. "Intervening conditions on the management of project risk: Dealing with uncertainty in information technology projects," International Journal of Project Management, Vol. 23, No. 8, pp. 591-599, 2005.

[33] Lebric, M. R and Choudrie, J. "A Dynamic Model of the Effects of Project Complexity on Time to Complete Construction Projects," International Journal of Innovation, Management and Technology, Vol. 2, No. 6, 2011 .

[34] Li D, G, Yamaguchi, D, Nagai, M. "A grey based decision -making approach to the supplier selection problem," Mathematical and Computer Modelling Vol.46, No.3-4, pp. 573- 581, 2007

[35] Li, Y and Liao, X. "Decision support for risk analysis on dynamic alliance," Decision support system Vol. 42, No.4, pp. 2043-2059, 2007.

[36] Ling F. Y.Y. "Key Determinants of Performance of Design-Bid-Build Projects in Singapore, Building Research and Information," Vol. 32, No. 2,March-April, pp.128-139, 2004.

[37] Loader, K.. What price competition? The management of competitive funding in UK Local Government", The International Journal of Public Sector Management, Vol.15, No.7, pp. 565-57, 2002

[38] Love, P.E.D., Skitmore, M. and Earl, G. (1998) "Selecting a suitable procurement method for a building project", Construction Management and Economics, vol. 16, no. 2, pp. 221-233, 1998.

[39] Lynda, B. Stakeholder Relationship Management, 2009 Edition

[40] Macheridis, N., and Nilsson, C.,(2004). Managing project complexity (Working paper) Lund, Sweden: Lund Institute of Economic Research, 2004

[41] McFarlan, F. W. Portfolio approach to information system, Harvard Business Review, Vol. 59, No.5, pp.142-150, 1981

[42] Maylor H. (2003), Project Management, Financial Times Prentice Hall. Pearsson Education Limited, 2003.

[43] Maylor, H., Vidgen, R., and Carver, S. "Managerial Complexity in Project- Based Operations: A Grounded Model and Its Implications for Practice," Project Management Journal, Vol. 39, pp.15-26, 2008

[44] Meijer, I. S. M., Hekkert, M. P., and Koppenjan, J. F.M. How Perceived Uncertainties Influence Transitions; the case of micro- CHP in The Netherlands," Technological Forecasting and Social Change, Vol.74, pp. 519-53, 2007.

[45] Newcombe, R. (2003), from client to project stakeholders: a stakeholder mapping approach. Construction Management and Economics, Vol. 22, No.8, pp. 762-784, 2003.
[46] Olander, S. and Landin, A. "Evaluation of stakeholder influence in the implementation of construction projects, International Journal of Project Management, Vol. 23, No4, pp. 321-328, 2005.

[47] Olander, S. "Stakeholder impact analysis in construction project management, Construction Management and Economics, Vol. 25: No. 3 pp. 277-287, 2007.

[48] Pheng L. S and Chuan, Q. T. " Environmental fact ors and work performance of project managers in the construction industry," International Journal of Project Management Vol.24, No1, pp.4-37, 2006

[49] PMI (Project Management Institute). Guide to the project management body of knowledge (PMBOK Guide). $3^{\text {rd }}$ ed. Newtown Square: Project Management Institute, 2008

[50] PMI (Project Management Institute). Guide to the project management body of knowledge (PMBOK Guide). 4thed. Newtown Square: Project Management Institute, 2008

[51] PMI (Project Management Institute). A Guide to the Project Management Body of Knowledge. Fifth ed. Newton Square, Pennsylvania: Project Management Institute, 2013.

[52] Raz, T., Shenhar, A. J., Dvir, D. (2002), Risk management, project success and technological uncertainty, $R$ and D Management, Vol. 32, No. 2, pp.101- 109, 2002.

[53] Ruben F, Ger M, Ranking construction project characteristics, in CIB Transformation through construction, K. Carter, S. Ogunlana and A. Kaka eds., pp.1-8, 2008. available at http://rubenfavie.com/media/1669/cib2008_ranking\%20construction\%20 project\%20characteristics. (Accessed on 8th Dec 2017)

[54] Sanderson, J. "Risk, uncertainty and governance in mega projects - A critical discussion of alternative explanations," International Journal of Project Management, Vol.30, No.4, pp.432-443, 2012.

[55] Sanvido, V., Grobler, F., Parfitt, K., Guvenis, M., and Coyle, M. "Critical Success Factors for Construction Projects," Journal of Construction Engineering and Management, Vol. 118, No. 1, pp. 94111, 1992.

[56] Shenhar, A. J. and Dvir, D. "Toward a Typological Theory of Project Management," Research Policy, Vol. 25, pp. 607-632, 1996.

[57] Shenhar, A. J. "One size does not fit all projects: exploring classical contingency domains," Management Science, Vol. 47, No. 3, pp. 394414, 2001

[58] Skitmore, R.M., and Marsden, D. E. "Which procurement system? Towards a universal procurement selection technique," Construction Management and Economics, Vol. 6, pp.71-89, 1998

[59] Sommer, S. C., Loch, C. H., and Dong, J. "Managing complexity and unforeseeable uncertainty in startup companies," An empirical study. Organization science, Vol. 20, No. 1, pp. 118-133, 2009.

[60] Turner, A. Building Procurement Macmillan, UK, 1990

[61] Turner, J.R., and Muller, R. Communication and co-operation on projects between the project owner as principal and the project manager as agent, European Management Journal, Vol. 22, No.3, pp. 327-336, 2005

[62] Vidal, L.A., and Marle, F. "Understanding project complexity: implications on project management," Kybernetes, Vol. 37, No.8, pp.1094-1110, 2005.

[63] Wallace, P., and Blumkin, M. "Major Construction Projects: Improving Governance and Managing Risks" Retrieved from www.deloitte.com, 2007. (Accessed on November, 2017)

[64] Ward, S. and Chapman, C. "Stakeholders and uncertainty management in projects," Construction Management and Economics, Vol. 26: No.6, pp.563-577, 2008

[65] Williams, T. M. "Assessing and moving on from the dominant project management discourse in the light of project overruns," IEEE Transactions on Engineering Management, Vol.52, No.4, 497-508, 2005

[66] Zwikael, O., and Ahn, M.,(2011). The effectiveness of risk management: An analysis of project risk management planning across industries and countries. Risk Analysis, Vol. 31, No.1, pp.25-37 